\title{
Water Management and Supply in a Mining Community - A Case Study of Tarkwa and its Environs*
}

\author{
C. B. Boye and A. A. Mensah
}

Boye, C. B. and Mensah, A. A. (2008). "Water Management and Supply in a Mining Community - A Case Study of Tarkwa and its Environs”, Ghana Mining Journal, pp. 9 - 13.

\begin{abstract}
Since mining activities require a lot of water and also increase population of host communities as a result of influx of workers, water resources in mining communities must be efficiently managed. This paper considered the various factors affecting water supply and its distribution in the Tarkwa area, a mining community, to find out the possible reasons for the inadequate water supply to Tarkwa. The maximum flood discharge for a reservoir constructed along the course of the River Bonsa was computed as $81.34 \mathrm{~m}^{3} / \mathrm{s}$ using the rational method for the estimation of peak flood flow. The volume of containment of the reservoir was also calculated from hydrographic surveys data to be $25456 \mathrm{~m}^{3}$. These results were analysed against the water demand vis-a-vis the current population growth. Also the condition of the equipment for pumping water both from the reservoir for treatment and after treatment to the storage tanks from where water is supplied to customers were considered together with the capacity of the treatment plant and the booster station at Bonsaso and Tamso respectively. It was concluded that the reservoir has enough water to meet the demand. However, the problem of inadequate supply was traced to non-regular power supply to both the treatment plant and booster station from where customers are served.
\end{abstract}

\section{Introduction}

Water is indispensable as far life of both plants and animals is concerned. Water is used by man for both domestic and industrial purposes. Different sources of water exist; such as rain water, underground water, surface water from streams or rivers and fresh water obtained from sea water through the process of desalination. Earlier studies conducted on water management in southwest Florida (Anon, 2001a) have proposed and implemented water resources preservation and management programmes in certain parts of the world to help protect springs, watersheds, aquifers storage and surface water all geared towards achieving sustainable water supply for current and future water supply needs. In southwest Florida for example, water conservation projects have been developed to aid reduce demand for water and increase efficient use, and to recognise the need to developing new water sources which include water conservation and reclamation (Anon, 2001a). In most developing countries however, not much efforts have been invested in water conservation projects, although it is becoming increasingly difficult to meet the water demand. The campaign to conserve and manage our natural water resources has not received the needed attention, as some people continue to farm along our natural water courses, while others engage in illegal felling of trees along the water shed. Some mining communities in developing country are faced with challenging water supply problems.

Tarkwa and its environs is a mining community with four mining companies with a cosmopolitan nature of population, having its inhabitants being predominantly either mine workers or providing some services to the mining companies. This community is however faced with inconsistent water supply and hence the water company cannot meet the demand of the people. Some of the major factors that may be attributed to the inadequate water supply are decreasing rainfall, lack of a proper water distribution system and population growth. This paper therefore seeks to investigate the factors identified as the possible causes of the problem of inadequate supply and distribution of water in the study area and make recommendation for improvement.

\section{Methodology}

Various studies were undertaken to estimate the volume of raw water available for processing (Antwi, 2007), the estimation of the amount of water used in a community (Kusi, 2007), the cost of producing treating water and the quality of water as against the standards set by the Environmental Protection Agency (EPA) and World Health Organization (WHO) (Odai, 2007). This paper considered the size of the containment of the reservoir that stores water for treatment, the quantity of water available (that is flood discharge) for processing, and the water demand as against the

\footnotetext{
* Manuscript received January 24, 2007

Revised version accepted October 14, 2008
} 
amount supplied by the water company and finally the pumping capacity of the available pumps used for propelling treated water.

\subsection{Hydrographic Surveys}

A hydrographic survey of the Bonsa reservoir and its immediate catchment area was carried out using the following instruments: a total station, targets and a sounding line for the depth of the reservoir. $\mathrm{X}, \mathrm{Y}$ and $\mathrm{Z}$ coordinates of selected points were obtained together with the surface level of the reservoir at the time of observation (Banister et al, 1997). The hydrographic survey was conducted to determine the volume of containment of the available reservoir.

\subsubsection{Computation of Volume of Water in the Res- ervoir}

Computer aided design software (Surfer) was used to generate a Digital Terrain Model (DTM) of the reservoir bed as well as its surface. The inverse distance weighting point interpolation technique (Anon, 2001b) was used with a weighted power of two (2), as the default value to model the river bed. Varying the $\mathrm{Z}$ coordinate to correspond with the surface water level, a second surface was generated. By selecting the End Area method of computing volumes between two surfaces, the volume enclosed in between the surfaces was be computed as shown in Figure 1. The End Areas method was then used to compute the volume between the two digital terrain surfaces created (Jones, 1998). The first surface was defined by entering the locations $(\mathrm{X}, \mathrm{Y})$, the identification numbers of the defined locations, and the elevations ( $\mathrm{Z}$ ) for the bed or the floor of the reservoir from which the bed elevation model was generated. The same procedure was repeated to define the water surface, in this case the locations and the identification numbers of the points remain the same but their elevations were made to correspond with the level of the water surface as at the time of observation.

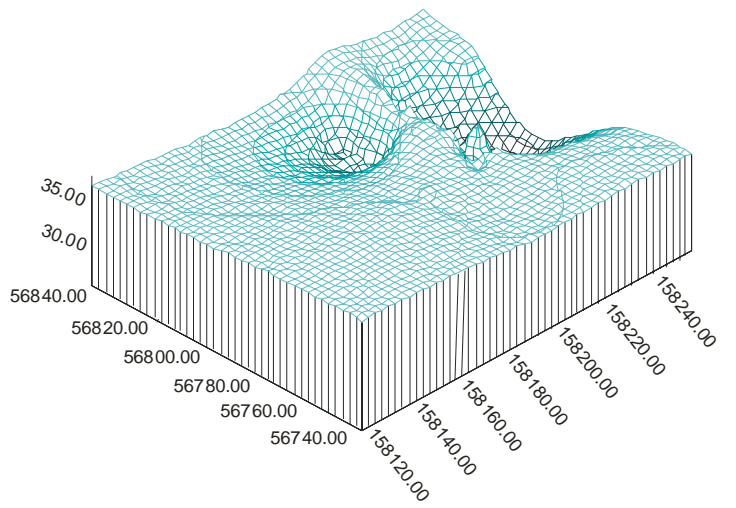

Fig. 1: The Digital elevation model of the Lower surface (bed of the Bonsa reservoir)

\subsection{Flood Discharge Estimation}

A topographic map at a scale of 1:50,000 covering the Bonsa River catchment was acquired and the upper catchment of the River to the reservoir was mapped out (Antwi, 2007). The rational method is one of the most widely used techniques in the estimation of peak flood flow and the design of suitable structures to accommodate it. The rational method was employed in the computation of the total flood discharge of the River catchment. In this method, the magnitude of the flood discharge depends on the following: the size of the catchment area, vegetation and soil type, catchment shape, available storage in lakes and swamps, and land use (Watkins and Fiddes, 1984).

The total flood discharge was computed with the formula: $\mathrm{Q}_{\max }=0.277 \mathrm{CAI}$

where $Q_{\max }=\operatorname{design}$ flood $\left(\mathrm{m}^{3} / \mathrm{s}\right)$,

$\mathrm{C}=$ runoff coefficient (between 0 and 1.0),

$\mathrm{A}=$ catchment area $\left(\mathrm{km}^{2}\right)$,

$\mathrm{I}=$ mean intensity of rainfall in $\mathrm{mm} / \mathrm{h}$ during the time of concentration.

The catchment area was computed to be $40.22 \mathrm{~km}^{2}$ obtained from the topographic map of scale 1:50000 using a planimeter with a constant of 1 : 2500. A run-off coefficient of 0.70 was used (selected from Appendix Table A1) considering a situation in which cultivation is taking place along the banks of the river, having steep slopes. Ideally, a flow duration curve constructed for the Bonsa River is required to determine the flow measurement over several years of observation. Since this information is unavailable, the duration of heavy rainfall during a typical flood producing storm in the area was used. The hypothetical values from Appendix table A2 were used with recurrence interval of 10 years, constants a and b being 66 and 0.2 respectively and $n$ a factor to allow for the retarding effect of different surfaces on overland flow being 0.73 . The Rainfall intensity I was computed from a suitable depth-duration equation as follows:

$$
\begin{aligned}
I & =\frac{a}{(b+T c)^{n}} \\
& =\frac{66}{(0.62+12.32)^{0.73}}=10.43 \mathrm{~mm} / \mathrm{hr}
\end{aligned}
$$

The value of the constants $a, b$ and $n$ were estimated from appendix Table A2. Time of Concentration $T_{c}$ is the time required for the most distant part of the catchment to contribute to the outflow at the reservoir site is computed using the formula (Watkins and Fiddes, 1984):

$$
\mathrm{T}_{\mathrm{c}}=2.8\left(\frac{L}{\sqrt{S}}\right)^{0.47}
$$


Where $\mathrm{L}$ is the length of the main stream $(\mathrm{km})$ and $\mathrm{S}$ is the main stream slope. Using the computed total length of $108.53 \mathrm{~km}$ and the mean slope of $21.51 \%$,

$\mathrm{T}_{\mathrm{c}}=2.8\left(\frac{108.53}{\sqrt{21.51}}\right)^{0.47}=12.32 \mathrm{hrs}$

Therefore, $\mathrm{Q}_{\max }=81.34 \mathrm{~m}^{3} / \mathrm{s}$.

\subsection{Estimation of Water Demand}

From 2005 population estimates for cities in Ghana, Tarkwa had an estimated population of 40,397 (Anon, 2004). Using a population growth rate of $3.4 \%$ (Anon, 2007), the population of Tarkwa from 1990 to 2020 was computed and shown in Table 1 . The amount of water used per month for selected households with known family sizes, were obtained from the University of Mines and Technology Estate Department. From the data collected the average water used per person per month was calculated to be $2.88 \mathrm{~m}^{3}$, which implies that $34.57 \mathrm{~m}^{3}$ of water is used per person per year. Using the estimated population and the water consumed per person per year the values for the estimated water required per year is computed as shown in Table 1. A combination of the computed water required and the amount supplied to Tarkwa from the GWC was used for the analysis of water demand in the study area taking cognizance of the population growth.

Table 1 Estimated Water required and quantity of water supplied by GWC

\begin{tabular}{|c|c|c|c|}
\hline Year & Population & $\begin{array}{c}\text { Est. Water } \\
\text { Required/year }\left(\mathrm{m}^{3}\right)\end{array}$ & $\begin{array}{c}\text { Water Supplied - } \\
\text { GWC }\left(\mathrm{m}^{3}\right)\end{array}$ \\
\hline 1990 & 36415 & 1258867 & 696527 \\
\hline 1995 & 37697 & 1303175 & 1059938 \\
\hline 2000 & 39024 & 1349042 & 939238 \\
\hline 2005 & 40397 & 1396524 & 957620 \\
\hline 2010 & 41770 & 1444006 & \\
\hline 2015 & 43191 & 1493102 & \\
\hline 2020 & 44659 & 1543868 & \\
\hline
\end{tabular}

A plot of the quantity of water required based on the estimated population from 1990 to 2020 is shown as against the quantity of water supplied by

\section{the GWC (Fig. 2).}

The monthly water supplied by the GWC between 1990 and 2005 is shown in Table 2 and a plot of these figures is shown (Figure 3).

Table 2 Quantity of Water Supplied between 1990 and 2005

\begin{tabular}{|c|c|c|c|c|}
\hline \multirow[b]{2}{*}{ Month } & \multicolumn{4}{|c|}{$\begin{array}{l}\text { Quantity of Water supplied to Tarkwa between the years } \\
1990 \text { and } 2005 \text { over a 5-year interval }\left(\mathrm{m}^{3}\right)\end{array}$} \\
\hline & 1990 & 1995 & 2000 & 2005 \\
\hline January & 16456 & 87000 & 85440 & 93120 \\
\hline February & 52159 & 89136 & 86690 & 67680 \\
\hline March & 59966 & 97882 & 94660 & 88480 \\
\hline April & 65956 & 45378 & 76480 & 74080 \\
\hline May & 51499 & 97545 & 77400 & 78000 \\
\hline June & 64095 & 93510 & 69490 & 82880 \\
\hline July & 72723 & 74294 & 65454 & 83200 \\
\hline August & 68182 & 101077 & 93172 & 77140 \\
\hline September & 55455 & 98891 & 18818 & 84040 \\
\hline October & 59363 & 111168 & 86400 & 70560 \\
\hline November & 65673 & 78043 & 93570 & 72950 \\
\hline December & 65000 & 86014 & 91664 & 85490 \\
\hline $\begin{array}{l}\text { Grand } \\
\text { Total }\end{array}$ & 696527 & 1059938 & 939238 & 957620 \\
\hline
\end{tabular}

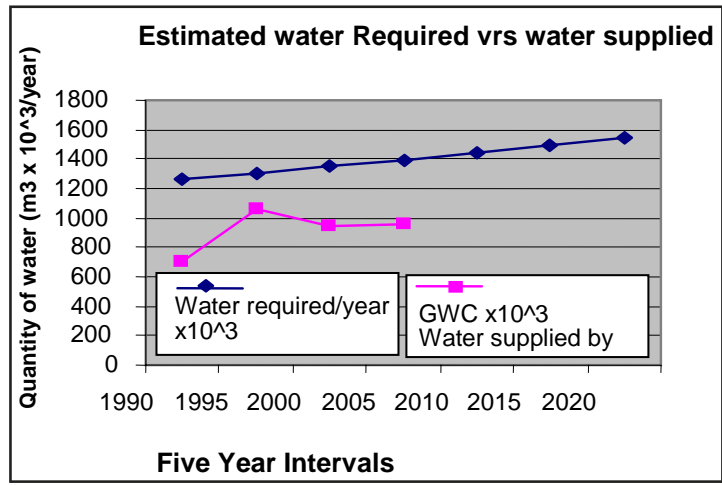

Fig. 2 Quantity of Water Required and that Supplied by the GWC Tarkwa from 1990 to 2020 .

\subsection{Water Pump Capacity}

A pair of water pumps each with an input energy of 190 and 175 kilowatts respectively are used at the treatment site and the booster station. Data on energy rating and capacity of pumps used for the distribution of water were calculated to be $220 \mathrm{~m}^{3}$

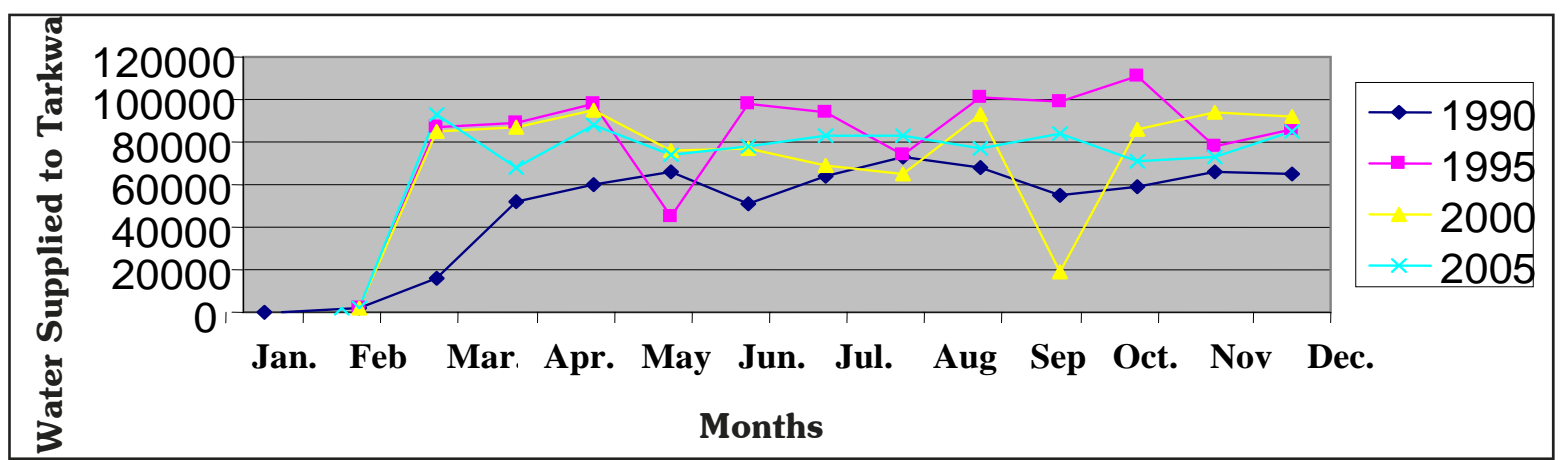

Fig. 3: Monthly Quantity of Water Supplied to Tarkwa between 1990 and 2005 
of water pumped per hour (GWC). Assuming 85\% efficiency for the pumps, a total of $4488 \mathrm{~m}^{3}$ of water is pumped per day.

\section{Discussions}

The computed maximum flow of water into the reservoir was $81.34 \mathrm{~m}^{3} / \mathrm{s}$, assuming $75 \%$ of this amount flows into the reservoir under normal conditions, which implies that during a normal flood period $61.00 \mathrm{~m}^{3}$ flows per second, and $3660.30 \mathrm{~m}^{3}$ of water flows through the reservoir per minute, which is equivalent to about $5270832.19 \mathrm{~m}^{3}$ of water per day. This indicates that for a greater part of the year, there is more water than the projected demand of $4394 \mathrm{~m}^{3}$ of water per day for the year, considering 2020 demand (Anon, 1994). Now, the volume of water in the reservoir when it has full capacity is $25456 \mathrm{~m}^{3}$ and can be used for a period of six days assuming no water from outside flows into the reservoir.

The reservoir is constructed along the natural water course; hence it will be continually recharged. From the quantity of water required and that supplied (Fig. 2) it can be inferred that the water demand is less than the inflow of water into the reservoir. This implies there is adequate water supply to meet the demand of the populace. However, the water supply (distribution) is less than the demand.

Water from the reservoir is then pumped into the designed chambers for treatment by water pumps which require energy supply. With a water pumping capacity of $220 \mathrm{~m}^{3}$ per hr, the quantity of water pumped per year is $1927200 \mathrm{~m}^{3}$. Considering a theoretical down time of $15 \%$ for maintenance of the plant, a total of $1638120 \mathrm{~m}^{3}$ of water is pumped per year which is more than the water required even for the year 2020 (see Fig. 2). The daily projected water demand multiplied by the number of days in a year gives $1603810 \mathrm{~m}^{3}$.

It was found from the studies that the electricity transmission lines supplying power to Bonsaso runs through some thick bamboo groves hence each time it rains heavily, with accompanying storms, some of the transmission lines get trapped by fallen bamboo tree branches causing short circuits and break in electrical contact with the source, thus stopping continuous running of the working pumps This break in electrical transmission takes a day or two of systematic inspection on the lines to identify and repair, during which period no water is supplied to customers. Thus the shortfalls experienced now must be due to irregular power supply to the treatment plant or the booster station. This can be inferred from Fig. 3 where it is observed that the least water supply to the treatment plant occurs during May and September which is during the raining season. Conse- quently, if reliable electricity could be supplied to the treatment plant, water supply to the communities would become adequate.

\section{Conclusions and Recommendation}

The study has shown that there is adequate flow of water into the reservoir which supplies water to the people of Tarkwa, and also the size of the containment of the reservoir is large enough to satisfy the water demand throughout the year and even during the dry season each year. The inadequate water supply to the communities was traced to nonregular power supply to the treatment plant at Bonsaso as a result of power disruption by vegetation (bamboo) along the power transmission lines when ever there is a rain storm.

Given the adequate conditions in terms of volume of water flow into the reservoir and the size required to contain enough water for supply, it is recommended that the GWC should put measures in place to considerably reduce waste and ensure steady power supply by adding standby generators to augment the power supply during the period of disruption.

\section{References}

Anon. (1994), “Reference Material” Water Com pany of Ghana, Accra, Ghana, unpublished, pp. 1-3.

Anon. (2001a), "Issue Papers - South West Flor ida Water Management District”, www.swfwmd.state.fl.us., Date accessed on: June, 26, 2007, 3 pp.

Anon. (2001b), "Ilwis 3.0 Academic" User's Guide, ITC Enschede, Netherlands, 430p.

Anon. (2004), “2005 population Estimates for cites in Ghana”, www.mongabay.com. Date accesses: May 15, 2007, pp. 1-2.

Anon., (2007), "The Wassa West District”, www.ghana districts.com. Date accesses: May 15, 2007, 1 p.

Antwi, N. N. (2007), "Estimation of Volume of water in a reservoir - A case study of Bonsa Water works", unpublished BSc. Project Report, University of Mines and Technol ogy, Tarkwa, pp. 13.

Banister, A., Raymond, S. and Baker, R. (1997), Surveying, Longman Singapore Publishers, $7^{\text {th }}$ edition, pp. 219-325, 416-498.

Jones, N. A. (1998), “The End Area Method”, www.sli.unimelb.edu.au/plane survey. Date accessed: June, 25, 2007, 1 p.

Kusi, K. A. (2007), "GIS and Drainage Model ling- A case study of the Densu River Ba sin” unpublished BSc. Project Report, Uni versity of Mines and Technology, Tarkwa, $19 \mathrm{pp}$.

Odai, L. N. A. (2007), “Water supply to Tarkwa in 
a changing mining Environment”, unpub lished BSc. Project Report, University of Mines and Technology, Tarkwa, 11 pp.

Watkins, L. H. and Fiddes, D. (1984), "Highway and Urban Hydrology in the Tropics", Pen tech Press, London, pp. 82, 141.

\section{Appendix}

Table A1 Runoff Coefficients

\begin{tabular}{|llll|}
\hline & \multicolumn{3}{c|}{ Average slope } \\
\hline Soil and Land Use & Mild & Medium & Steep \\
\hline & $(0-4 \%)$ & $(4-10 \%)$ & $(10 \%+)$ \\
\hline Rock, heavy clay & 0.60 & 0.75 & 0.85 \\
\hline Intense cultivation, loamy/clay soils & 0.50 & 0.60 & 0.70 \\
\hline Grass cover, medium soils & 0.40 & 0.50 & 0.60 \\
\hline Dense vegetation, forest & 0.05 & 0.15 & 0.25 \\
\hline
\end{tabular}

(Source: Fiddes and Watkins, 1984)

Table A2 Estimated Values of Intensity Duration Equation Constants-Seawell Airport

\begin{tabular}{|l|c|c|c|c|}
\hline Available data & $\begin{array}{c}\text { Recurrence } \\
\text { interval (yr) }\end{array}$ & $\mathrm{b}$ & $\mathrm{n}$ & $\mathrm{a}$ \\
\hline 1and 24h only & 2 & 0.1 & 0.71 & 36 \\
\hline 1and 24h only & 5 & 0.2 & 0.73 & 55 \\
\hline 1and 24h only & 10 & 0.2 & 0.73 & 66 \\
\hline Maxima recorded & 28 & $0.4+$ & 0.79 & 106 \\
\hline
\end{tabular}

(Source: Fiddes and Watkins, 1984)

Table A3 Water Consumption Table - Using UMaT Staff a as Case Study

\begin{tabular}{|c|c|c|c|}
\hline $\begin{array}{l}\text { House } \\
\text { Numbers }\end{array}$ & Family size & $\begin{array}{l}\text { Average quantity of water } \\
\text { consumed per month }\end{array}$ & $\begin{array}{l}\text { Average quantity of water } \\
\text { consumed perperson/ month }\end{array}$ \\
\hline 1 & 4 & 11.27 & 2.82 \\
\hline 2 & 5 & 8.10 & 1.62 \\
\hline 3 & 6 & 8.80 & 1.47 \\
\hline 4 & 11 & 14.00 & 1.27 \\
\hline 5 & 7 & 14.60 & 2.09 \\
\hline 6 & 1 & 8.00 & 8.00 \\
\hline 7 & 1 & 8.00 & 8.00 \\
\hline 8 & 6 & 8.10 & 1.35 \\
\hline 9 & 5 & 7.10 & 1.42 \\
\hline 10 & 6 & 8.90 & 1.48 \\
\hline 11 & 5 & 16.90 & 3.38 \\
\hline 12 & 3 & 8.00 & 2.67 \\
\hline 13 & 5 & 6.25 & 1.25 \\
\hline 14 & 5 & 7.00 & 1.40 \\
\hline 15 & 5 & 11.23 & 2.25 \\
\hline 16 & 5 & 10.08 & 2.02 \\
\hline 17 & 7 & 9.20 & 1.31 \\
\hline 18 & 8 & 8.90 & 1.11 \\
\hline 19 & 3 & 8.60 & 2.87 \\
\hline 20 & 1 & 10.00 & 10.00 \\
\hline 21 & 6 & 19.25 & 3.21 \\
\hline 22 & 5 & 24.64 & 4.93 \\
\hline 23 & 6 & 12.43 & 2.07 \\
\hline 24 & 6 & 7.88 & 1.31 \\
\hline 25 & 4 & 7.88 & 1.97 \\
\hline 26 & 4 & 8.00 & 2.00 \\
\hline 27 & 4 & 14.00 & 3.50 \\
\hline 28 & 4 & 10.00 & 2.50 \\
\hline 29 & 4 & 10.00 & 2.50 \\
\hline 30 & 7 & 19.00 & 2.71 \\
\hline 31 & 2 & 19.00 & 9.50 \\
\hline 33 & 7 & 29.10 & 4.16 \\
\hline 34 & 6 & 30.00 & 5.00 \\
\hline 35 & 7 & 23.20 & 3.31 \\
\hline 36 & 6 & 12.36 & 2.06 \\
\hline 37 & 13 & 16.72 & 1.29 \\
\hline 38 & 14 & 26.75 & 1.91 \\
\hline 39 & 16 & 20.16 & 1.26 \\
\hline 40 & 14 & 10.00 & 0.71 \\
\hline 41 & 7 & 11.00 & 1.57 \\
\hline & & & 2.88 \\
\hline
\end{tabular}

The average quantity of water consumed perperson in a month $=2.88 \mathrm{~m}$

\section{Authors}

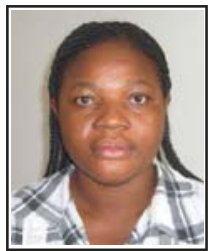

C.B. Boye (Mrs.) holds a masters degree in GeoInformatics from the International Institute of Geo Information and Earth sciences (ITC), Enschede, Netherlands, and a BSc degree in Geodetic Engineering from the Kwame Nkrumah University of Science and Technology, Kumasi, Ghana. She worked with Kasap Ltd as a geodetic engineer on various road and building projects. In 2004 she joined the University of Mines and technology (UMaT) Tarkwa where she lectures in Engineering Surveying, Cadastral Surveying, Photogrammetry and Remote Sensing. She a member of the Ghana Institution of Engineers, the African Association of Remote Sensing and Environment (AARSE), and an academic member of the Federation of International Surveyors (FIG). She is currently the head of the Geomatic engineering Department.

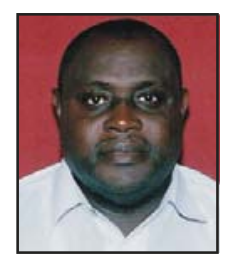

A. A. Mensah holds an MPhil degree in Mineral Resources Engineering with special emphasis on Geomatics from the University of Nottingham in the UK and a Diploma in Mining Engineering. In 1988, he joined the UST School of Mines (Currently The University of Mines and Technology) where he now lectures in Introduction to Geomatics, Surveying Instrumentation, Instrumentation Control, Mine and Underground Surveying. He is currently a member of the Ghana Institution of Surveyors (GhIS) and an academic member of the Federation of International Surveyors (FIG). 